\title{
molecules
}

ISSN 1420-3049

www.mdpi.com/journal/molecules

Article

\section{Antioxidant Effects of Some Drugs on Ethanol-induced Ulcers}

Mira Popovic ${ }^{1, *}$, Snezana Janicijevic-Hudomal ${ }^{2}$, Biljana Kaurinovic ${ }^{1}$, Julijana Rasic ${ }^{2}$ and Svetlana Trivic ${ }^{1}$

${ }^{1}$ Department of Chemistry, Faculty of Science, University of Novi Sad, Trg Dositeja Obradovica 3, 21000 Novi Sad, Serbia

${ }^{2}$ Institute of Pharmacology, Faculty of Medicine, University of Pristina (Kosovska Mitrovica), Serbia

* Author to whom correspondence should be addressed; E-mail: popovic@ih.ns.ac.yu; Tel.: +381214852770; Fax: +38121454065.

Received:12 November 2008; in revised form: 20 January 2009 / Accepted: 6 February 2009 / Published: 18 February 2009

\begin{abstract}
The aim of this work was to investigate the antioxidant potential of some commonly used drugs (bromocriptine, haloperidol and azithromycin) on alcohol-induced ulcers in the rat. The following parameters were determined: content of reduced glutathione, activities of catalase, xanthine oxidase, glutathione reductase, glutathione peroxidase, peroxidase, and lipid peroxidation intensity. A battery of biochemical assays were used and the resulting data was statistically analyzed. Alcohol stress caused gastric ulcerations and hemorrhages and changed all the examined parameters except glutathione peroxidase activity. All drugs reduced the ulcer index and hemorrhages, with azithromycin showing the strongest effects. The drugs in combination with alcohol showed different effects on biochemical parameters. Our results indicate that the gastroprotective effects of the investigated drugs on experimental lesions induced by $100 \%$ ethanol could not be correlated with their antioxidative properties.
\end{abstract}

Keywords: Alcohol stress; Stomach; Bromocriptine; Haloperidol; Azithromycin; Antioxidative status. 


\section{Introduction}

Oxidative stress plays an important role in the pathogenesis of more than 100 diseases [1]. Experimental studies have demonstrated that oxygen-generated free radicals (ROS) and lipid peroxidation are involved in the pathogenesis of acute gastric lesions induced by ethanol, nonsteroidal anti-inflammatory drugs or Helicobacter pylori [2-5].

Azithromycin (AZA) is an antibiotic with immunomodulatory effects which exhibits rapid and prolonged cellular accumulation, especially within phagocytes and shows anti-inflammatory action towards acute inflammation. Azithromycin also displays antioxidant effects [6]. Potential mechanisms of action include inhibition of cytokine release, neutrophyl function and mediator release, stimulation of apoptosis, as well as inhibition of mucus secretion [7-9].

Bromocriptine (BRC), with potent D2 receptor agonistic and mild D1 receptor antagonistic action, is widely used in the treatment of Parkinson's disease and in a broad spectrum of psychiatric disorders [10]. Its mode of action is both central and peripheral and dose dependent. BRC has recently been shown to possess strong free radical scavenging action and antioxidant properties both in vitro and in vivo $[11,12]$.

Haloperidol (HP) is a widely used neuroleptic drug used in the treatment of acute and chronic psychosis, e.g., schizophrenia. Haloperidol is thought to exert its clinical effects through cerebral dopamine D2-receptors and $\delta$-opioid receptors [13]. Chronic treatment with neuroleptics increases free radical production and oxidative stress, and decreases the activity of antioxidant defense enzymes [14, 15].

Numerous studies have shown that dopamine agonists such as bromocriptine, apomorphine L-Dopa and others, as well as dopamine antagonists such as haloperidol, domperidon, sulpirid etc., play a role in the modulation of stress ulcers, through dopamine receptors, both peripherally and centrally [16-18].

The commonly used medications bromocriptine, haloperidol and azythromycin have different chemical structures and different pharmacological actions, yet despite this they can all exert similar effects on the biochemical parameters examined in this work in the presence of alcohol.

The aim of this work was to investigate the effects of bromocriptine, haloperidol and azithromycin on alcohol-induced ulcers, hemorrhages and antioxidative status of the stomach in experimental animals. For this purpose we measured catalase (CAT, E.C. 1.11.1.6), peroxidase (Px, E.C. 1.11.1.7), glutathione peroxidase (GSHPx, E.C. 1.11.1.9), glutathione reductase (GR. E.C. 1.6.4.2) and xanthine oxidase (XOD, E.C. 1.2.3.2) activities, reduced glutathione (GSH) content and lipid peroxidation (LPx) intensity.

\section{Results and Discussion}

In Table 1 we present the values of the measured parameters from stomachs of animals treated with alcohol in combination with bromocriptine, haloperidol and azithromycin. The GSH content was significantly reduced in all groups compared to the OO control group (untreated animals). A statistically significant decrease in GSH content was observed for the AH (alcohol + haloperidol, 25 $\mathrm{mg} / \mathrm{kg} \mathrm{bw}$ ) and AB2 (alcohol + bromocriptine, $37.5 \mathrm{mg} / \mathrm{kg}$ bw) groups compared to the AO control (alcohol treated animals). 
Glutathione peroxidase activity was practically identical in both control groups, indicating that alcohol treatment did not change the activity of the enzyme. The glutathione peroxidase activity remained unchanged in all groups as compared to both controls (OO and $\mathrm{AO}$ ).

Alcohol-induced stress (AO group) increased the activity of glutathione reductase in a statistically significant manner. The activity of glutathione reductase was significantly reduced in all groups compared to the AO control group. In comparison to the $\mathrm{OO}$ group it was also significantly reduced in all groups except the AB3 (alcohol + bromocriptine, $25 \mathrm{mg} / \mathrm{kg} \mathrm{bw}$ ) and AH groups.

The peroxidase activity was significantly increased in all groups in comparison with the OO control. However, in all other groups no significant changes in Px activity were observed compared to the AO group.

Activity of catalase (CAT) was significantly decreased in the following groups compared to the OO control: $\mathrm{AO}, \mathrm{AB} 2, \mathrm{AB} 3$ and $\mathrm{AH}$. On the other hand, a statistically significant increae of the CAT activity was recorded in the $\mathrm{AB} 1$ (alcohol + bromocriptine, $12.5 \mathrm{mg} / \mathrm{kg} \mathrm{bw}$ ), AB2, AB3 and AA (alcohol + azithromycin) groups, compared to the AO control group.

Table 1. Investigated biochemical parameters.

\begin{tabular}{|c|c|c|c|c|c|c|c|}
\hline Enzymes & OO group & AO group & AB1 group & AB2 group & AB3 group & AH group & AA group \\
\hline GSH & $1.55 \pm 0.07$ & $0.91 \pm 0.08^{c}$ & $0.87 \pm 0.03^{c}$ & $0.77 \pm 0.05^{\mathrm{c}, \mathrm{d}}$ & $0.90 \pm 0.04^{c}$ & $0.78 \pm 0.03^{\mathrm{c}, \mathrm{e}}$ & $0.82 \pm 0.05^{c}$ \\
\hline GSHPx & $0.92 \pm 0.10$ & $0.91 \pm 0.09$ & $0.90 \pm 0.07$ & $0.89 \pm 0.06$ & $1.01 \pm 0.13$ & $1.06 \pm 0.09$ & $0.99 \pm 0.11$ \\
\hline GSHR & $1.21 \pm 0.04$ & $1.42 \pm 0.14^{\mathrm{a}}$ & $0.99 \pm 0.04^{\mathrm{c}, \mathrm{f}}$ & $0.80 \pm 0.02^{\mathrm{c}, \mathrm{f}}$ & $1.17 \pm 0.11^{\mathrm{d}}$ & $1.19 \pm 0.05^{\mathrm{e}}$ & $1.08 \pm 0.08^{\mathrm{c}, \mathrm{e}}$ \\
\hline Px & $2.10 \pm 0.07$ & $2.93 \pm 0.36^{b}$ & $2.46 \pm 0.21^{\mathrm{a}}$ & $2.48 \pm 0.13^{b}$ & $3.40 \pm 0.28^{c}$ & $3.11 \pm 0.22^{c}$ & $3.26 \pm 0.33^{\mathrm{b}}$ \\
\hline CAT & $2.11 \pm 0.19$ & $0.57 \pm 0.14^{\mathrm{c}}$ & $1.88 \pm 0.17^{\mathrm{f}}$ & $0.90 \pm 0.18^{c, d}$ & $1.25 \pm 0.12^{\mathrm{c}, \mathrm{f}}$ & $0.52 \pm 0.12^{\mathrm{c}}$ & $2.47 \pm 0.28^{\mathrm{f}}$ \\
\hline XOD & $3.25 \pm 0.12$ & $1.63 \pm 0.21^{\mathrm{c}}$ & $4.12 \pm 0.16^{\mathrm{c}, \mathrm{f}}$ & $4.55 \pm 0.20^{\mathrm{b}, \mathrm{f}}$ & $3.66 \pm 0.13^{\mathrm{a}, \mathrm{f}}$ & $5.11 \pm 0.14^{\mathrm{c}, \mathrm{f}}$ & $4.74 \pm 0.36^{\mathrm{b}, \mathrm{f}}$ \\
\hline LPx & $0.23 \pm 0.04$ & $0.35 \pm 0.09^{\mathrm{c}}$ & $0.41 \pm 0.02^{c}$ & $0.11 \pm 0.01^{\mathrm{b}, \mathrm{e}}$ & $0.33 \pm 0.02^{\mathrm{c}}$ & $0.33 \pm 0.03^{b}$ & $0.30 \pm 0.03^{\mathrm{a}}$ \\
\hline Ulcers index & & $16.20 \pm 8.75$ & $8.92 \pm 4.79^{\mathrm{d}}$ & $9.53 \pm 4.22^{\mathrm{d}}$ & $12.00 \pm 5.92$ & $4.50 \pm 1.50^{\mathrm{d}}$ & $0.00 \pm 0.00^{\mathrm{f}}$ \\
\hline Hemorrhages & $\begin{array}{l}\text { stomach } \\
\text { without } \\
\text { change }\end{array}$ & $\begin{array}{l}\text { pronounced } \\
\text { submucosal } \\
\text { hemorrhages }\end{array}$ & $\begin{array}{l}\text { hemorrhages } \\
\text { of lower } \\
\text { intensity }\end{array}$ & $\begin{array}{l}\text { hemorrhages } \\
\text { similar to the } \\
\text { control OO } \\
\text { group }\end{array}$ & $\begin{array}{l}\text { pronounced } \\
\text { submucosal } \\
\text { hemorrhages }\end{array}$ & $\begin{array}{l}\text { hemorrhages } \\
\text { present }\end{array}$ & $\begin{array}{l}\text { significantly } \\
\text { smaller change } \\
\text { compared to } \\
\text { the control, } \\
\text { hemorrhages } \\
\text { practically } \\
\text { absent. }\end{array}$ \\
\hline
\end{tabular}

Activities of: XOD, CAT, PX, GSHPx and GSHR are expressed in $\mathrm{nmol} / \mathrm{mg}$ of protein $\cdot \mathrm{min}^{-1}$

Intensity of lipid peroxidation is expressed in nmol malondialdehyde/mg protein

Content of GSH is expressed in $\mathrm{nmol} \mathrm{GSH} / \mathrm{mg}$ protein

$\mathrm{n}=5$; compared to OO group: $\mathrm{p}>0.05$ (statistically insignificant), ${ }^{\mathrm{a}} \mathrm{p}<0.05,{ }^{\mathrm{b}} \mathrm{p}<0.01,{ }^{\mathrm{c}} \mathrm{p}<0.001$;

compared to AO group: $p>0.05$ (statistically insignificant), ${ }^{\mathrm{d}} \mathrm{p}<0.05,{ }^{\mathrm{e}} \mathrm{p}<0.01,{ }^{\mathrm{f}} \mathrm{p}<0.001$

Xanthine oxidase activity was statistically significantly reduced in the AO group, compared to the OO control, while it is statistically significantly increased in all other groups compared to both controls. 
The lipid peroxidation (LPx) intensity was significantly increased in all groups, except AB2, compared to the $\mathrm{OO}$ control. In the $\mathrm{AB}$ group a statistically significant decrease was recorded compared to both control groups (OO and $\mathrm{AO})$.

Using one-way ANOVA (one-way analysis of variance) and Tukey Snedecor test F and D values, parameters which presents the total variability values and significance of differences observed between groups were assessed.

Table 2. ANOVA test for measured biochemical parameters.

\begin{tabular}{|c|c|c|c|c|c|c|c|c|c|c|c|c|c|}
\hline GSH & 00 & $\mathrm{~A} 0$ & $\mathrm{AB} 1$ & AB2 & AB3 & $\mathrm{AH}$ & GSHPx & 00 & $\mathrm{~A} 0$ & $\mathrm{AB} 1$ & $\mathrm{AB} 2$ & AB3 & $\mathrm{AH}$ \\
\hline A0 & $\begin{array}{c}3.61 \\
+\end{array}$ & & & & & & A0 & $\begin{array}{c}0.01 \\
-\end{array}$ & & & & & \\
\hline AB1 & $\begin{array}{c}3.24 \\
+\end{array}$ & $\begin{array}{c}0.37 \\
-\end{array}$ & & & & & AB1 & $\begin{array}{c}0.01 \\
-\end{array}$ & $\begin{array}{c}0.01 \\
-\end{array}$ & & & & \\
\hline AB2 & $\begin{array}{c}2.18 \\
+\end{array}$ & $\begin{array}{c}1.44 \\
+\end{array}$ & $\begin{array}{c}1.07 \\
+\end{array}$ & & & & AB2 & $\begin{array}{c}0.02 \\
-\end{array}$ & $\begin{array}{c}0.01 \\
-\end{array}$ & $\begin{array}{c}0.01 \\
-\end{array}$ & & & \\
\hline AB3 & $\begin{array}{c}4.36 \\
+\end{array}$ & $\begin{array}{c}0.75 \\
+\end{array}$ & $\begin{array}{c}1.12 \\
+\end{array}$ & $\begin{array}{c}2.18 \\
+\end{array}$ & & & AB3 & $\begin{array}{c}0.09 \\
+\end{array}$ & $\begin{array}{c}0.10 \\
+\end{array}$ & $\begin{array}{c}0.11 \\
+\end{array}$ & $\begin{array}{c}0.11 \\
+\end{array}$ & & \\
\hline AH & $\begin{array}{c}2.29 \\
+\quad \\
\end{array}$ & $\begin{array}{c}1.32 \\
+ \\
\end{array}$ & $\begin{array}{c}0.95 \\
+ \\
\end{array}$ & $\begin{array}{c}0.12 \\
-\end{array}$ & $\begin{array}{c}2.06 \\
+\end{array}$ & & AH & $\begin{array}{c}0.14 \\
+\end{array}$ & $\begin{array}{c}0.14 \\
+\end{array}$ & $\begin{array}{c}0.15 \\
+\end{array}$ & $\begin{array}{c}0.16 \\
+\end{array}$ & $\begin{array}{c}0.04 \\
-\end{array}$ & \\
\hline AA & $\begin{array}{c}2.68 \\
+\end{array}$ & $\begin{array}{c}0.93 \\
+\end{array}$ & $\begin{array}{c}0.56 \\
+\end{array}$ & $\begin{array}{c}0.51 \\
+\end{array}$ & $\begin{array}{c}1.68 \\
+\end{array}$ & $\begin{array}{c}0.39 \\
-\end{array}$ & AA & $\begin{array}{c}0.08 \\
+\end{array}$ & $\begin{array}{c}0.09 \\
+\end{array}$ & $\begin{array}{c}0.09 \\
+\end{array}$ & $\begin{array}{c}0.10 \\
+\end{array}$ & $\begin{array}{c}0.02 \\
-\end{array}$ & $\begin{array}{c}0.06 \\
-\end{array}$ \\
\hline GSHR & 00 & $\mathrm{~A} 0$ & $\mathrm{AB} 1$ & $\mathrm{AB} 2$ & $\mathrm{AB} 3$ & $\mathrm{AH}$ & $\mathbf{P x}$ & 00 & $\mathrm{~A} 0$ & $\mathrm{AB} 1$ & $\mathrm{AB} 2$ & $\mathrm{AB} 3$ & $\mathrm{AH}$ \\
\hline A0 & $\begin{array}{c}12.07 \\
+\end{array}$ & & & & & & A0 & $\begin{array}{c}0.91 \\
+\end{array}$ & & & & & \\
\hline AB1 & $\begin{array}{c}7.78 \\
+\end{array}$ & $\begin{array}{c}4.30 \\
+\end{array}$ & & & & & AB1 & $\begin{array}{c}0.46 \\
+\end{array}$ & $\begin{array}{c}0.45 \\
+\end{array}$ & & & & \\
\hline AB2 & $\begin{array}{c}5.87 \\
+ \\
\end{array}$ & $\begin{array}{c}6.21 \\
+ \\
\end{array}$ & $\begin{array}{c}1.91 \\
+ \\
\end{array}$ & & & & AB2 & $\begin{array}{c}0.33 \\
+ \\
\end{array}$ & $\begin{array}{c}0.58 \\
+ \\
\end{array}$ & $\begin{array}{c}0.13 \\
- \\
\end{array}$ & & & \\
\hline AB3 & $\begin{array}{c}13.58 \\
+\quad \\
\end{array}$ & $\begin{array}{c}1.51 \\
+ \\
\end{array}$ & $\begin{array}{c}5.81 \\
+ \\
\end{array}$ & $\begin{array}{c}7.72 \\
+ \\
\end{array}$ & & & AB3 & $\begin{array}{c}0.50 \\
+ \\
\end{array}$ & $\begin{array}{c}1.41 \\
+ \\
\end{array}$ & $\begin{array}{c}0.96 \\
+ \\
\end{array}$ & $\begin{array}{c}0.83 \\
+ \\
\end{array}$ & & \\
\hline AH & $\begin{array}{c}9.63 \\
+ \\
\end{array}$ & $\begin{array}{c}2.44 \\
+ \\
\end{array}$ & $\begin{array}{c}1.86 \\
+ \\
\end{array}$ & $\begin{array}{c}3.77 \\
+ \\
\end{array}$ & $\begin{array}{c}3.95 \\
+ \\
\end{array}$ & & AH & $\begin{array}{c}1.41 \\
+ \\
\end{array}$ & $\begin{array}{c}0.50 \\
+ \\
\end{array}$ & $\begin{array}{c}0.95 \\
+ \\
\end{array}$ & $\begin{array}{c}1.09 \\
+ \\
\end{array}$ & $\begin{array}{c}1.91 \\
+ \\
\end{array}$ & \\
\hline AA & $\begin{array}{c}8.67 \\
+ \\
\end{array}$ & $\begin{array}{c}3.40 \\
+ \\
\end{array}$ & $\begin{array}{c}0.89 \\
+ \\
\end{array}$ & $\begin{array}{c}2.81 \\
+ \\
\end{array}$ & $\begin{array}{c}4.91 \\
+ \\
\end{array}$ & $\begin{array}{c}0.96 \\
+ \\
\end{array}$ & AA & $\begin{array}{c}2.98 \\
+ \\
\end{array}$ & $\begin{array}{c}2.07 \\
+ \\
\end{array}$ & $\begin{array}{c}2.52 \\
+ \\
\end{array}$ & $\begin{array}{c}2.65 \\
+ \\
\end{array}$ & $\begin{array}{c}3.48 \\
+ \\
\end{array}$ & $\begin{array}{c}1.57 \\
+ \\
\end{array}$ \\
\hline CAT & 00 & A0 & $\mathrm{AB} 1$ & $\mathrm{AB} 2$ & AB3 & $\mathrm{AH}$ & XOD & 00 & $\mathrm{~A} 0$ & $\mathrm{AB} 1$ & $\mathrm{AB} 2$ & $\mathrm{AB} 3$ & $\mathrm{AH}$ \\
\hline A0 & $\begin{array}{c}1.53 \\
+\end{array}$ & & & & & & A0 & $\begin{array}{c}1.82 \\
+\end{array}$ & & & & & \\
\hline AB1 & $\begin{array}{c}0.23 \\
+\end{array}$ & $\begin{array}{c}1.30 \\
+\end{array}$ & & & & & AB1 & $\begin{array}{c}0.67 \\
+\end{array}$ & $\begin{array}{c}2.49 \\
+\end{array}$ & & & & \\
\hline
\end{tabular}


Table 2. Cont.

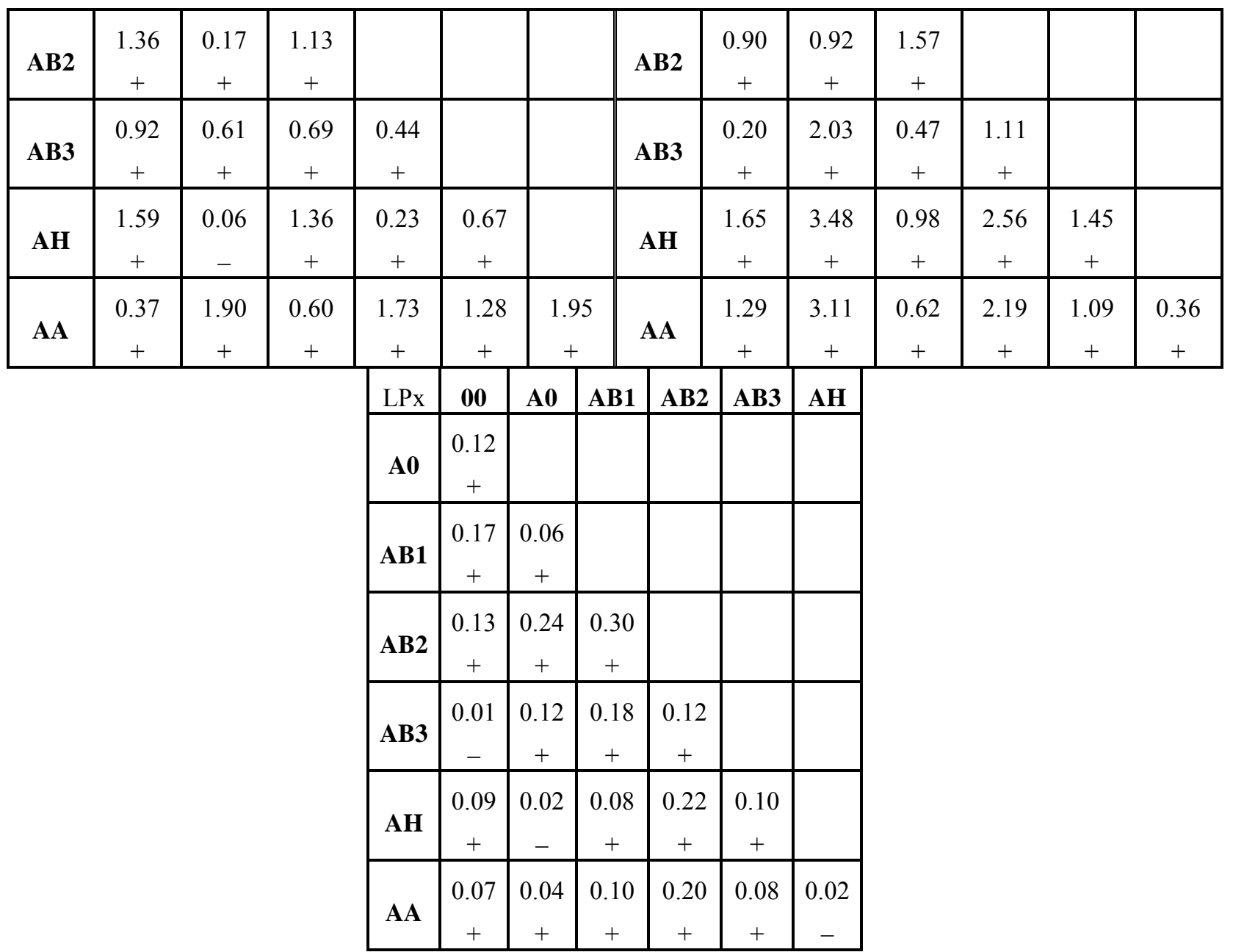

Results of the ANOVA test are represented for the differences between groups for the confidence level $\mathrm{p}<0.05$; + statistically significant $\mathrm{p}<0.05$; - statistically nonsignificant $\mathrm{p}>0.05$; GSH: $\quad \mathrm{F}=$ 26.99, $\mathrm{p}<0.001 ; \mathrm{D}=0.40$; GSHPx: $\mathrm{F}=1.94, \mathrm{p}>0.05 ; \mathrm{D}=0.08$; GSHR: $\mathrm{F}=102.51 ; \mathrm{p}<0.001 ; \mathrm{D}$ $=0.66 ;$ XOD: $\mathrm{F}=140.52 ; \mathrm{p}<0.001 ; \mathrm{D}=0.17$;AT: $\mathrm{F}=92.53 ; \mathrm{p}<0.001 ; \mathrm{D}=0.14 ; \mathrm{LPx}: \mathrm{F}=$ $21.64 ; \mathrm{p}<0.001 ; \mathrm{D}=0.03 ; \mathrm{Px}: \mathrm{F}=38.71 ; \mathrm{p}<0.001 ; \mathrm{D}=0.31$

GSH content was not significantly changed between the AO/AB1, AB2/AH and AH/AA groups. There was also no statistically significant difference between the following group combinations: $\mathrm{AB} 3 / \mathrm{OO}, \mathrm{AH} / \mathrm{AO}$ and $\mathrm{AA} / \mathrm{AH}$ in the case of LPx. Analysis of the activity of glutathione reductase (GSHR) and xanthine oxidase (XOD) pointed to statistically significant changes between all tested groups. CAT and Px activity showed that all group combinations have statistical significance differences except: $\mathrm{AO} / \mathrm{AH}$ for $\mathrm{CAT}$ and $\mathrm{AB} 1 / \mathrm{AB} 2$ for Px. GSHPx showed statistically insignificant differences in nine tested combinations. This further supports our experimental finding (Table 1) that there is no change in the activity of enzymes in all tested groups compared to the OO control. Based on results presented in Table 1 we can conclude that alcohol induced stress significantly affects the biochemical parameters of oxidative status investigated in this work with the exception of the activity of glutathione peroxidase.

Compared to the AO group ulcer index and hemorrhages were significantly decreased in all groups, except the AB3 group (Table I). Alcohol-induced stress led to changes in the stomach indicated by 
profuse submucosal hemorrhages. Changes observed as erosions and petechiae, were confirmed pathohistologically as defects in mucosa and submucosal hemorrhages. In comparison with the AO group, the ulcer index was decreased by all tested drugs and the best protective effect was observed in the AA group.

Results obtained in these experiments show a decrease in GSH content in animals treated with alcohol (AO group) compared to the control group (OO). GSH content could be decreased by its binding to acetaldehyde [19] due to elevated activity of gastric alcohol dehydrogenase (high ethanol concentration) leading to increased acetaldehyde concentration. It can also be decreased as a consequence of enzymatic or non-enzymatic GSH oxidation with ROS. Increased lipid peroxidation (LPx) intensity could also be one of the factors leading to the decrease in GSH content seen in this work. Thus, GSH could not exhibit its protective effects in animals, neither as an antioxidant nor in conjugation processes. Since GSHPx activity was not changed in comparison with the OO group, $\mathrm{H}_{2} \mathrm{O}_{2}$ probably could not affect GSH content. Furthermore, the activity of GSHR is significantly increased in the AO group alone, while in all combinations of the AO group with those treated with drugs it is reduced.

In the examination performed by La Casa et al. [20] it was established that ethanol causes a marked reduction in the mucosal non-protein SH content, expressed as GSH levels in rats. In addition, GSHPx activity decreases in gastric mucosa after ethanol treatment. Thiobarbituric acid-reactive substances in the gastric mucosa, used as an index of lipid peroxidation, increased markedly after administration of $50 \%$ ethanol.

Px activity was increased in all groups, especially in AB3, compared to OO group. High alcohol concentration leads to an NADH increase during ethanol conversion to acetaldehyde in the presence of gastric alcohol dehydrogenase. Hydrogen peroxide could be also produced by metabolization of ethanol and drugs. Increased NADH and hydrogen peroxide concentration could increase peroxidase activity, leading to decrease of substrate concentration for catalase.

Activity of CAT was decreased in $\mathrm{AO}, \mathrm{AB} 2, \mathrm{AB} 3$ and $\mathrm{AH}$, and increased in the $\mathrm{AA}$ group compared to the $\mathrm{OO}$ group. The decrease in CAT levels leads to an increase in the accumulation of ROS, which can elevate the intensity of lipid peroxidation, tissue damage and increased peroxidase activity.

Xanthine oxidase is a major source of ROS generation in the pathogenesis of various biological systems including the gastrointestinal tract [21]. XOD activity was decreased in AO group. In all other groups, particularly in $\mathrm{AH}$ group, it was increased, compared to both controls. Elevated XOD activity suggests that production of $\operatorname{ROS}\left(\mathrm{O}_{2}{ }^{-\bullet}\right.$ and $\left.\mathrm{H}_{2} \mathrm{O}_{2}\right)$ is increased, what may lead to increased activity of antioxidant enzymes and LPx intensity. The effects of these drugs on alcohol-induced stress in the liver under the same experimental conditions gave similar values for the biochemical parameters studied in this work [22].

The highest ulcer index was observed in the AO group, while in the AA group it was similar to the control (OO). Furthermore, the ulcer index was recorded for all other groups, and values were found to be significantly lower, except in the AB3 group, compared to the AO group. Our results suggest that other processes besides lipid damage can lead to ulcerative injuries of mucosal membranes of the stomach, and that stress-induced ulcers are caused by an increase in free radical generation apart from acid pepsin factors. 
Naidu et al. [23] showed that chronic treatment of rats with HP significantly increases LPx intensity, and decreases GSH content and SOD and catalase activity. Our results are in accordance with these results, although we used the acute treatment in our investigation.

Since bromocriptine effects are dose dependent, we applied three different doses. All of them had similar effects on the parameters investigated, probably due to bromocriptine scavenger activity [12]. The best gastroprotective effect was exerted azithromycin, which showed antioxidant effects as well [6].

Alcohol stress caused gastric ulcerations and hemorrhages and changed all of the examined biochemical parameters, except glutathione peroxidase activity. The effects of drugs on ethanol treated animals were variable. Sometimes they increased the analyzed parameters and sometimes they diminished it. However, the only direct measure of oxidative stress (i.e., TBARS levels) does not support the conclusion that drugs are gastroprotecive by an antioxidant mechanism. Only group AB2 had a significant decrease in TBARS. All other ethanol treated groups had values greater than control (OO).

All the tested drugs reduced the ulcer index and hemorrhage, with azithromycin showing the strongest effect. Importantly, AZA inhibits hemorrhaging completely and leaves ulcer index levels similar to control levels. Our results indicate that the gastroprotective effects of the investigated drugs on experimental lesions induced by $100 \%$ ethanol could not be correlated with their antioxidative properties.

\section{Experimental}

\section{General}

This investigation was conducted on sexually mature males of laboratory Wistar rats, with an average body weight of 200-230 grams and ages up to 3 months. Rats were bred in the vivarium at the Centre for Biomedical Investigation, Galenika a.d. Animals were kept in standard Plexiglass cages at constant room temperature $22 \pm 1^{\circ} \mathrm{C}$, with circadian rhythm (day/night), and were fed standard laboratory rat feed, produced by the Veterinary Institute in Zemun. The number of rats was five per cage. Animals were treated according to the principles of the International Declaration Guide for Care and Use of Laboratory Animals (NIH publication № 85-23). Before the experiment, all animals were exposed to a 24-hour fasting period prior to treatment with alcohol, but had free access to water, and were put in metabolic plexiglass cages with a wire floor to prevent coprofagia. Average single doses of investigated drugs were selected on the basis of human dosage and Clark's formula. Experiments were conducted in the same day interval $(8-15 \mathrm{~h})$. Alcohol stress was induced by intragastric administration of $1 \mathrm{~mL}$ of $100 \%$ alcohol [24] Animals were returned to metabolic cages, but no water was given to them. After one hour, animals were sacrificed in ether narcosis. Animals that were not exposed to such stress and were not treated with any drugs were used as a control group.

The following drugs were used in the experiments: Bromocriptine ${ }^{\circledR}$ (2.5 $\mathrm{mg}$ tablets, Zdravlje, Leskovac, Serbia), dissolved in distilled water immediatey prior to administration; Haldol ${ }^{\circledR}$ decanoate (haloperidol decanoate, $50 \mathrm{mg} / 1 \mathrm{~mL}$ ampoule, Janssen-Cilag, Division of Johnson \& Johnson S.E. d.o.o., Ljubljana, Slovenia); Hemomycin ${ }^{\circledR}$ (azithromycin, $200 \mathrm{mg} / 5 \mathrm{~mL}$, Hemofarm, Vrsac, Serbia). Of 
the drugs used in this study, only in the case of bromocriptine did we study the dose dependency since this drug has a wide therapeutic window in comparison with the other two.

\section{Animal treatment}

OO group- control - (untreated animals), AO group - alcohol (control without drugs), AB1 group alcohol + bromocriptine, $24 \mathrm{~h} \mathrm{n.g.} \mathrm{prior} \mathrm{to} \mathrm{stress} 12.5 \mathrm{mg} / \mathrm{kg}$ bw. AB2 group - alcohol + bromocriptine n.g. $24 \mathrm{~h}$ prior to stress $37.5 \mathrm{mg} / \mathrm{kg}$ bw; AB3 group - alcohol + bromocriptine n.g. $3 \mathrm{~h}$ prior to stress $25 \mathrm{mg} / \mathrm{kg} \mathrm{bw}$; AH group - alcohol + haloperidol i.p. 30 minutes prior to stress $25 \mathrm{mg} / \mathrm{kg}$ bw; AA group - alcohol + azithromycin n.g. $250 \mathrm{mg} / \mathrm{kg}$ bw during 5 days prior to stress, on the fifth day $2.5 \mathrm{~h}$ prior to stress.

Measurement of macroscopic changes in stomach epithelia following alcohol-induced stress

Gastric lesion induction and evaluation: Upon treatment, animals were sacrificed, and the abdomen was opened by midline incision, the stomach was removed, opened along the greater curvature, rinsed gently with water, and pinned open for macroscopic examination and for photodocumentation using a Canon Power Shot A40 digital camera. Areas with gastric lesions were measured by planimetry, using Get Area Lite for Corel Draw 11, and the ulcer index (UI) was estimated from the formula:

$$
\mathrm{UI}=\left[\text { ulcerated area }\left(\mathrm{mm}^{2}\right) / \text { total stomach area }\left(\mathrm{mm}^{2}\right)\right]
$$

Results are expressed as mean \pm SD. Statistical analysis was done using the t-test. Differences with $\mathrm{p}<0.05$ were considered to be significant. The ulcer index and the hemorrhaging area are the main indicators used in this work to estimate the anti-ulcer effects of the studied drugs.

Biochemical assays: Animals were decapitated after treatment and the stomach was extracted. The stomach was homogenized in a Potter homogenizer with TRIS-HCl/sucrose in a ratio of $1: 3$ at $4^{\circ} \mathrm{C}$. Obtained homogenates were filtered and the following biochemical parameters were determined: Extent of lipid peroxidation, LPx, was determined after Buege and Aust [25], peroxidase (Px) activity was measured after Simon et al. [26] and the effect of catalase (CAT) after Beers and Sizer [27]. Glutathione peroxidase (GSH-Px) activity was evaluated as described in Chin et al. [28], xanthine oxidase (XOD) after Bergmayer [29], glutathione reductase (GSHR) after Glatzle and Vuillenmir [30], and reduced glutathione content (GSH) after Kapetanović and Mieyal [31]. The total protein content was determined after Gornall et al. [32]

Statistical analysis: Results of biochemical analyses are presented as the mean value \pm standard deviation (S.D.). The difference between control and test groups was analyzed using the Student t-test (significant difference at $\mathrm{p} \leq 0.05$ confidence level). Using one-way ANOVA (one-way analysis of variance) and Tukey Snedecor test F and D values, parameters which presents the total variability values and significance of diferenecs observed between groups, were assessed. 


\section{Acknowledgements}

The Ministry of Sciences and Environmental Protection, Republic of Serbia, supported this research.

\section{References and Notes}

1. Niki, E.; Yoshida Y.; Saito Y.; Noguchi N. Lipid peroxidation: Mechanisms, inhibition, and biological effects. Biochem. Biophys. Res. Commun. 2005, 338, 668-676.

2. Hollander, D.; Tarnawski, A.; Krause, W. J.; Gergely, H. Protective effect of sucralfate against alcohol induced gastric mucosal injury in the rat. Macroscopic, histologic, ultrastructural, and functional time sequence analysis. Gastroenterology 1985, 88, 366-374.

3. Das, D.; Banerjee, R.K. Effect of stress on the antioxidant enzymes and gastric ulceration. Mol. Cell. Biochem. 1993, 25, 115-125.

4. Das,D.; Bandyopadhyay, D.; Bhattacharjee, M.; Banerjee, R.K. Hydroxyl radical is the major causative factor in stress-induced gastric ulceration. Free Radical. Biol. Med. 1997, 23, 8-18.

5. Das, D.; Bandyopadhyay, D.; Banerjee, R.K. Oxidative Inactivation of Gastric Peroxidase by Site-Specific Generation of Hydroxyl Radical and Its Role in Stress-Induced Gastric Ulceration Free Radical. Biol. Med. 1998, 24, 460-469.

6. Bakar, O.; Demircay, Z.; Yuksel, M.; Haklar, G.; Sanisoglu, Y. The Effect of Azithromycin on Reactive Oxygen Species in Rosacea. Clin. Exper. Derm. 2007, 32, 197-200.

7. Parnham, M. J.; Čulić, O.; Eraković, V.; Munić, V.; Popović-Grle, S.; Barišić, K.; Bosnar, M.; Brajša, K.; Čepelak, I.; Čužić, S.; Glojnarić, I.; Manojlović, Z.; Novak-Mirčetić, R.; Oresković, K.; Pavičić-Beljak, V.; Radošević, S.; Sučić, M. Modulation of neutrophil and inflammation markers in chronic obstructive pulmonary disease by short-term azithromycin treatment. Eur. J. Pharm. 2005, 517, 132-143.

8. Culic, O.; Erakovic, V.; Cepelak, I.; Barisic, K.; Brajsa, K.; Ferencic, Z.; Galovic, R.; Glojnaric, I.; Manojlovic, Z.; Munic, V.; Novak-Mircetic, R.; Pavicic-Beljak, V.; Sucic, M.; Veljaca, V.; Zanic-Grubisic, T.; Parnham, M.J. Azithromycin modulates neutrophil function and circulating inflammatory mediators in healthy human subjects Eur. J. Pharmacol. 2002, 450, 277-289.

9. Tsai, W.C.; Rodriguez, M.L.; Young, K.S.; Deng, J.C.; Thannickal, V.J.; Tateda, K.; Hershenson, M.B.; Standiford, T.J. Azithromycin Blocks Neutrophil Recruitment in Pseudomonas Endobronchial Infection. Am. J. Respir. Crit. Care Med. 2004, 170, 1331-1339.

10. Sitland-Marken, P.A.; Wells, B.G.; Froemming, J.H.; Chu, C.C.; Brown, C.S. Psychiatric applications of bromocriptine therapy. J. Clin. Psychiatry 1990, 51, 68-82.

11. Muralkrishnan, D.; Mohanakumar, K.P. Neuroprotection by Bromocriptine Against 1-Methyl-4Phenyl-1,2,3,6-Tetrahydropyridine-Induced Neurotoxicity in Mice. FASEB J. 1998, 12, 905-912.

12. Yoshikawa, T.; Minamiyama, Y.; Naito, Y.; Kondo, M. Antioxidant Properties of Bromocriptine, a Dopamine Agonist. J. Neurochem. 1994, 62, 1034-1038.

13. Post, A.; Holsboer, F.; Behl, C. Induction of NF-kB Activity during Haloperidol-Induced Oxidative Toxicity in Clonal Hippocampal Cells: Suppression of NF-kB and Neuroprotection by Antioxidants. J. Neurosci. 1998, 18, 8236-8246. 
14. Naidu, P.S.; Singh, A.; Kulkarni, S.K. Quercetin, a Bioflavonoid, Attenuates Haloperidol-Induced Orofacial Dyskinesia. Neuropharmacology 2003, 44, 1100-1106.

15. Yao, J.K.; Reddy, R.; McElhinny, L.G.; van Kammen, D.P. Effects of Haloperidol on Antioxidant Defense System Enzymes in Schizophrenia. J. Phys. Res. 1998, 32, 385-391.

16. Sikiric, P.; Mikus, D.; Seiwerth, S.; Grabarevic, Z.; Rucman, R.; Petek, M. et al. Pentadecapeptide BPC 157, Cimetidine, Ranitidine, Bromocriptine, and Atropine Effect in Cysteamine Lesions in Totally Gastrectromized Rats (A Model for Cytoprotective Studies) Dig. Dis. Sci. 1997, 42, 1029-1037.

17. Samini, M.; Moezi, L.; Jabarizadeh, N.; Tavakolifar, B.; Shafaroodi, H.; Dehpour, A.R. Evidences for involvement of nitric oxide in the gastroprotective effect of bromocriptine and cyclosporin A on water immersion stress-induced gastric lesions. Pharmacol. Res. 2002, 46, 519523

18. Degen, S.B.; Geven, E.J.W.; Sluyter, F.; Hof, M.W.P.; Van der Elst, M.C.J.; Cools, A.R. Apomorphine-susceptible and apomorphine-unsusceptible Wistar rats differ in their recovery from stress-induced ulcers. Life Sci. 2003, 72, 1117-1124.

19. Lieber, C,S; Leo, M.A. Metabolism of ethanol and some associated adverse effects on the liver and the stomach. Recent Dev. Alcohol 1998; 14, 7-40.

20. La Casa, C.; Villegas, I.; Alarcón de la Lastra, C.; Motilva, V.; Martín Calero, M.J. Evidence for protective and antioxidant properties of rutin, a natural flavone, against ethanol induced gastric lesions. J. Ethnopharm. 2000, 71, 45-53.

21. Huh, K.; Kwon, T.H.; Shin, U.S.; Kim, W.B.; Ahn, B.O.; Oh, T.Y.; Kim J-A. Inhibitory effects of DA-9601 on ethanol-induced gastrohemorrhagic lesions and gastric xanthine oxidase activity in rats. J. Ethnopharmacol. 2003, 88, 269-273.

22. Popovic, M.; Janicijevic-Hudomal, S.; Kaurinovic, B.; Rasic, J.; Trivic, S. Effects of Various Drugs on Alcohol-induced Oxidative Stress in the Liver. Molecules 2008, 13, 2249-2259.

23. Naidu, P.S.; Singh, A.; Kulkarni, S.K. Effect of Withania somnifera root extract on haloperidolinduced orofacial dyskinesia: possible mechanisms of action. J. Med. Food 2003, 6, 107-114.

24. Arafa, H.M.M.; Sayed-Ahmed, M.M. Protective role of carnitine esters against alcohol-induced gastric lesions in rats. Pharmacol. Res. 2003, 48, 285-290.

25. Buege, A.J.; Aust, D.S. In Methods in Enzymology; Fleischer, S., Parker L., Eds.; Academic Press: New York, U.S.A., 1988; p. 306.

26. Simon, L.M.; Fatrai, Z.; Jonas, D.E.; Matkovics, B. Study of Metabolism Enzymes during the Development of Phaseolus vulgaris. Biochem. Physiol. Plant 1974, 166, 389-393.

27. Beers, R.F.J.; Sizer, J.W. Spectrophotometric Method for Measuring of Breakdown of Hydrogen Peroxide by Catalase. J. Biol. Chem. 1950, 195, 133-140.

28. Chin, P.T.Y.; Stults, F.H.; Tappel, A.L. Purification of Rat Lung Soluble Glutathione Peroxidase. Biochem. Biophys. Acta 1976, 445, 558-660.

29. Bergmayer U.H. Methoden Der Enzymatischen Analyse. Verlag Chemie: Weinhem, 1970.

30. Glatzle, D.; Vuillenmir, K. Glutathione Reductase Test with Whole Blood a Convenient Procedure for the Assessment of the Riboflavin Status in Human. Experimentia 1974, 30, 565 638. 
31. Kapetanović, I.M.; Mieyal, I.I. Inhibition of Acetaminophen Induced Hepatotoxicity by Phenacetin and Its Alkoxy Analogs. J. Pharmacol. Exp. Ther. 1979, 209, 25-30.

32. Gornall, H.G.; Nardwall, C.L. Estimation of Total Protein in Tissue Homogenate. J. Biol.Chem. 1949, 177, 751-756.

Sample Availability: Samples are not available.

(C) 2009 by the authors; licensee Molecular Diversity Preservation International, Basel, Switzerland. This article is an open-access article distributed under the terms and conditions of the Creative Commons Attribution license (http://creativecommons.org/licenses/by/3.0/). 